\title{
Profile of alectinib for the treatment of ALK-positive non-small cell lung cancer (NSCLC): patient selection and perspectives
}

This article was published in the following Dove Press journal: OncoTargets and Therapy

\author{
Niki Karachaliou ${ }^{1,2}$ \\ Manuel Fernandez Bruno' \\ jillian \\ Wilhelmina Paulina Bracht ${ }^{2}$ \\ Rafael Rosell ${ }^{2-5}$ \\ 'Institute of Oncology Rosell (IOR), \\ University Hospital Sagrat Cor, \\ QuironSalud Group, Barcelona, Spain; \\ ${ }^{2}$ Molecular and Cellular Oncology \\ Laboratory, Pangaea Oncology, \\ Laboratory of Molecular Biology, Quiron- \\ Dexeus University Institute, Barcelona, \\ Spain; ${ }^{3}$ Institut d'Investigació en Ciències \\ Germans Trias i Pujol, Badalona, Spain; \\ ${ }^{4}$ Catalan Institute of Oncology, Medical \\ Oncology Service, Hospital Germans \\ Trias i Pujol, Badalona, Spain; ${ }^{5}$ Instituto \\ Oncológico Dr Rosell (IOR), \\ Quirón-Dexeus University Institute, \\ Barcelona, Spain
}

\begin{abstract}
Discovered in 2007, anaplastic lymphoma kinase (ALK) gene rearrangements positive (ALK+) lung cancers compose a small subset of non-small cell lung cancer (NSCLC), with rapidly expanded treatments. There are currently several ALK inhibitors, including crizotinib, ceritinib, alectinib, brigatinib, and lorlatinib which have been licensed by the US Food and Drug Administration or the European Medicines Agency for the treatment of ALK+ NSCLC patients. Along with the multiple therapies, the survival of this subtype of NSCLC has been significantly expanded, even for patients whose disease has spread in the brain. Alectinib (Alecensa), a specific ALK and rearranged during transfection tyrosine kinase inhibitor is approved as first-line therapy for metastatic ALK+ NSCLC patients. It is additionally approved for ALK + NSCLC previously treated with crizotinib. The main aim of this review is to assemble on the efficacy of alectinib for the treatment of $\mathrm{ALK}+\mathrm{NSCLC}$, to elaborate the activity of the drug in the central nervous system, and to debate on which is the position of this compound in the treatment course of ALK+ lung cancer patients.
\end{abstract}

Keywords: anaplastic lymphoma kinase, alectinib, lung cancer

\section{Introduction}

Precision medicine has made a great impact in the survival of patients with advanced non-small cell lung cancer (NSCLC), particularly those with epidermal growth factor receptor $(E G F R)$ mutations or echinoderm microtubule-associated protein-like 4 (EML4)-anaplastic lymphoma kinase ( $A L K$ ) fusions (ALK+). ${ }^{1,2}$ Alterations of the $A L K$ gene were initially described in anaplastic large cell lymphoma (hence the name of the gene). ${ }^{3,4}$ ALK alterations have a role in the pathogenesis of inflammatory myofibroblastic tumors and neuroblastomas. ${ }^{4,5}$ In NSCLC, $A L K$ fusions, which join the exons 1-13 of the EML4 gene to exons 20-29 of $A L K$ gene, ${ }^{6}$ were discovered in 2007. ${ }^{7,8}$

$A L K$ fusions are present in 3-5\% of NSCLC and are more common in young patients with lung adenocarcinoma and non-smoking history. ${ }^{9,10}$ Initially ALK+ patients were treated with chemotherapy until the discovery of crizotinib, an ALK, MET and ROS1 tyrosine kinase inhibitor (TKI), which has demonstrated its superiority compared to standard platinum-based chemotherapy in several clinical trials in ALK+ patients. ${ }^{11-13}$ As happens with other targeted therapies, resistance to crizotinib soon appears due to ALK-dependent or ALK-independent mechanisms. ${ }^{14-16}$ Furthermore, the central nervous system (CNS) is a frequent site of metastases in ALK+ NSCLC patients with approximately $26 \%$ of them having CNS metastases at the time of the diagnosis. ${ }^{17}$ The
Correspondence: Rafael Rosell Cancer Biology \& Precision Medicine Program, Catalan Institute of Oncology, Hospital Germans Trias i Pujol, Ctra Canyet, s/n, Badalona 08916, Spain Tel +34934978925

Email rrosell@iconcologia.net 
incidence of CNS metastases increases during the course of the disease to as high as $60 \%$ for crizotinib-resistant ALK+ patients. ${ }^{17}$ Still, stage IV ALK+ NSCLC patients have prolonged survival. ${ }^{18}$ Median survival of 6.8 years can be achieved with the appropriate medical care in stage IV ALK+ NSCLC patients. ${ }^{19}$ This is due to the development of several second- and third-generation ALK TKIs, like ceritinib, $^{20-21}$ alectinib, $^{22-24}$ brigatinib,25 and lorlatinib ${ }^{26,27}$ which have expanded the treatment options of ALK+ NSCLC (Figure 1). Ensartinib, entrectinib and repotrectinib are under clinical investigation. ${ }^{28-30}$ It is worth mentioning that ALK + NSCLC patients have better clinical outcome with pemetrexed chemotherapy, compared to wild-type NSCLC patients or those with other genetic alterations like KRAS mutations. $^{31}$ The differential outcome to pemetrexed chemotherapy may be attributed to the lower levels of thymidylate synthase in ALK+ compared to wild-type NSCLC patients. ${ }^{31}$

Alectinib (marketed as Alecensa) was created at Chugai Kamakura Research Laboratories, which is part of the Hoffmann-La Roche group, as an oral ALK inhibitor. Alectinib is approved for the first-line therapy of ALK + NSCLC patients as well as for patients pretreated with crizotinib (Figure 1). ${ }^{32}$ In preclinical studies, alectinib was able to inhibit the growth of $E M L 4-A L K$ positive tumor cells. It has also shown activity against ALK+ cells with the gatekeeper $A L K$ L1196M mutation, which confers resistance to crizotinib. ${ }^{33,34}$ However, this activity has not been reconfirmed in the clinical setting. ${ }^{35}$ Alectinib inhibits ALK autophosphorylation as well as the phosphorylation of signal transducer and activator of transcription 3 (STAT3). ${ }^{33}$

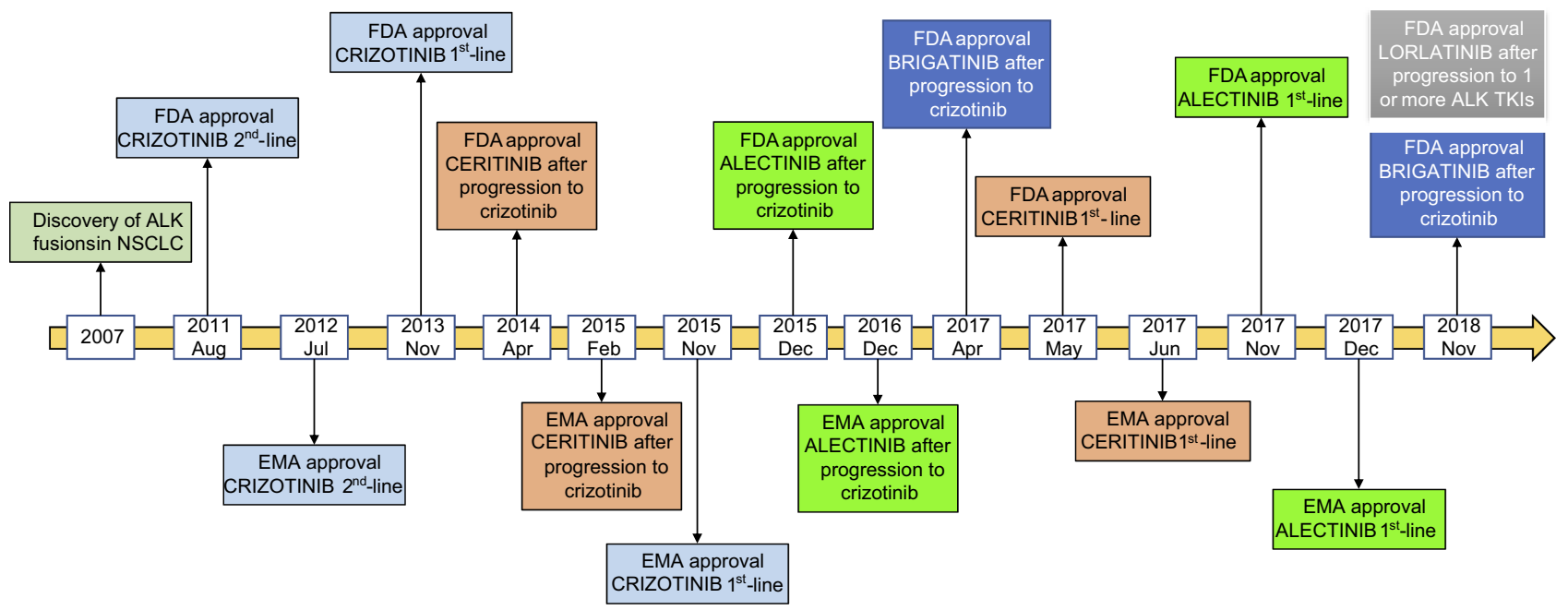

Alectinib is also a highly selective rearranged during transfection (RET) inhibitor. ${ }^{36}$ Fusions of the RET gene, such as KIF5B (the kinesin family 5B gene)-RET, CCDC6 (coiled-coil domain containing 6)-RET, and others are driver oncogenes in $1-2 \%$ of lung adenocarcinomas. ${ }^{37,38}$ Alectinib inhibits RET phosphorylation and the tumor growth in xenograft models with $R E T$ fusions. ${ }^{36,39}$ It also has activity against RET gatekeeper mutations, like V804L and V804M. ${ }^{36,39}$ Currently, alectinib is in clinical trials for $R E T$-rearranged NSCLC. In this review, we will not focus on the activity of alectinib on RET-rearranged tumors, especially because other more specific RET inhibitors are in clinical development. ${ }^{40-43}$

In this review, we will discuss the clinical status of alectinib in ALK+ NSCLC patients, outline its clinical development, and CNS activity, and comment on the place of alectinib in the management of ALK+ NSCLC patients. Mechanisms of resistance to alectinib will be also revised.

\section{Alectinib in the second-line setting of ALK+ NSCLC patients}

The Phase I/II study AF-002JG study was performed in crizotinib-resistant ALK+ NSCLC patients, and established $600 \mathrm{mg}$ of alectinib twice daily as the recommended Phase II dose. ${ }^{44}$ The study showed promising antitumor activity of alectinib including in patients with brain metastases. ${ }^{44}$ Indeed, the AF-002JG study confirmed the alectinib CNS penetration. Specifically, a 52\% objective response rate (ORR) was observed among 21 patients with baseline brain metastases. In all patients who underwent CNS sampling, measurable

Figure I ALK inhibitors approved for the treatment of ALK+ NSCLC patients.

Abbreviations: NSCLC, non-small cell lung cancer; FDA, Food and Drug Administration; EMA, European Medicines Agency; TKI, Tyrosine kinase inhibitor; ALK, Anaplastic lymphoma kinase. 
concentrations of alectinib were detected. ${ }^{44}$ In Japan, $300 \mathrm{mg}$ twice daily was tested in ALK + NSCLC patients who had progressed to previous chemotherapy (Phase I/II AF-001JP study). ${ }^{45}$ In an updated analysis of the AF-001JP study, median progression-free survival (PFS) was not reached (3-year PFS rate, $62 \%$; 95\% CI 45, 75) and the 3 -year overall survival (OS) rate was $78 \%{ }^{46}$

Two Phase II studies evaluated the effect of alectinib in ALK + NSCLC patients who had progressed on crizotinib (Table 1). ${ }^{47,48}$ Most of the patients in both studies had received chemotherapy before crizotinib and had brain metastases at inclusion. ${ }^{4,48}$ ORRs of 49 (95\% CI 40, 58) and $48 \%(95 \%$ CI 36, 40) were observed in the global NP28673 and the North American NP28761 studies, respectively. ${ }^{47,48}$ An updated analysis of the NP28673 with a longer follow-up of 21 months confirmed the ORR of $51 \%(95 \%$ CI 42,60$)$ with a duration of response (DoR) of 15.2 months $(95 \%$ CI 11.2, 24,9). Median PFS to alectinib was 8.9 months $(95 \%$ CI 5.6, 12,8), and median OS was 26 months (95\% CI 11.2, not estimable) (Table 1). ${ }^{49}$ Similarly, an updated analysis of NP28761 with a followup of 17 months reported an ORR of 52\% (95\% CI 40, 65), with a DoR of 15 months. Median PFS and OS were 8 and 22.7 months, respectively. ${ }^{50} \mathrm{~A}$ pooled analysis of the NP28673 and NP28761 studies demonstrated an ORR of $51 \%(95 \% \mathrm{CI} 44,59)$, a disease control rate of $79 \%(95 \% \mathrm{CI}$ $72,84)$, and a median DoR of 14.9 months (95\% CI 11.1, 20.4). ${ }^{51}$ Median PFS was 8.3 months $(95 \%$ CI $7.0,11.3)$ and median OS was 26.0 months $(95 \%$ CI 21.4, not estimable). ${ }^{51}$ Based on the results of the NP28673 and NP28761 studies, on 11 December 2015, the US Food and Drug Administration (FDA) granted accelerated approval to alectinib for the treatment of ALK + NSCLC patients who have progressed on or are intolerant to crizotinib. One year later, on 15 December 2016, the European Medicines Agency (EMA) approved alectinib for the same indication.

The Phase III ALUR clinical trial compared alectinib versus chemotherapy in ALK+ metastatic NSCLC patients whose disease had progressed after platinum-based chemotherapy and after crizotinib (Table 1). ${ }^{22}$ One hundred seven patients were randomized $2: 1$ to receive alectinb or chemotherapy (pemetrexed or docetaxel). More than threethirds of the patients had brain metastases at baseline. ${ }^{22}$ Median PFS was significantly longer with alectinib compared to chemotherapy, as assessed both by the investigators (9.6 months [95\% CI 6.9, 12.2; alectinib] and 1.4 months [95\% CI 1.3,1.6; chemotherapy], HR 0.15 [95\% CI 0.08, 0.29 ]; $\mathrm{P}<0.001)$ and by an independent review committee
(IRC) (7.1 months [95\% CI 6.3,10.8, alectinib] and 1.6 months [95\% CI 1.3,4.1, chemotherapy], HR 0.32 [95\% CI 0.17, 0.59]; $\mathrm{P}<0.001$ ) (Table 1). ${ }^{22}$ The ORR was $38 \%$ with alectinib versus 3\% with chemotherapy. Median investigator-assessed DoR was 9.3 months (95\% CI 6.9, not estimable; alectinib) versus 2.7 months (95\% CI not estimable; chemotherapy) (Table 1). ${ }^{22}$ No significant differences were observed in OS between the two treatment arms of the ALUR study, probably due to the trial design, which was permitting patients in the chemotherapy arm to cross over to alectinib therapy once disease progression was noted. ${ }^{22}$

Alectinib penetrates through the blood-brain barrier,44 and it is retained within the CNS. The brain protective effect of alectinib has been attributed to the fact that alectinib is not a substrate of the efflux transporters P-glycoprotein (P-gp) and breast cancer resistance protein). ${ }^{32}$ In the ALUR study, those patients who had brain metastases at baseline had an ORR in CNS of 54\% in the alectinib arm, compared to $0 \%$ in the chemotherapy arm. $^{22}$ Alectinib was able to reduce $86 \%$ the risk of progression in patients with baseline brain metastases. The 6-month cumulative incidence rate of CNS progression was $11 \%$ with alectinib and $48 \%$ with chemotherapy. A significantly higher CNS disease control rate of $80 \%$ was observed in the alectinib-treated patients compared to $27 \%$ for those who received chemotherapy $(\mathrm{P}<0.001){ }^{22}$ Overall, the ALUR study showed a striking benefit of alectinib versus standard second-line chemotherapy in ALK+ NSCLC patients.

\section{Alectinib in the first-line setting of ALK+ NSCLC patients}

The first Phase III trial which compared alectinib (at the dose of $300 \mathrm{mg}$ twice daily) with crizotinib in the first-line setting of ALK+ NSCLC patients took place in Japan (J-ALEX). ALK inhibitor-naïve Japanese patients, who may have received or not previous chemotherapy, were included in the study. ${ }^{23}$ Overall, median PFS was not estimable (95\%CI 20.3, not estimable) at the time of the analysis in the alectinib group compared to 10.2 months $(95 \%$ CI $8.2,12.0)$ in the crizotinib group (HR 0.34 [99.7\% CI 0.17, 0.71]; $\mathrm{P}<0.0001$ ). ${ }^{23}$ For treatment-naïve patients, median PFS was not estimable (95\% CI 17.5, not estimable) with alectinib versus 10.2 months $(95 \%$ CI 8.3, 13.9) for those receiving crizotinib (HR 0.31 [95\% CI 0.17, 0.57]). For patients previously treated with chemotherapy, median PFS was 20.3 months (95\% CI 20.3 , not estimable) in the alectinib group versus 8.2 months 
Table I Clinical trials of alectinib

\begin{tabular}{|c|c|c|c|c|c|c|c|}
\hline \multirow[t]{2}{*}{ Study } & \multirow[t]{2}{*}{ Phase } & \multirow[t]{2}{*}{ Design } & \multirow[t]{2}{*}{ Population } & \multicolumn{4}{|l|}{ Results } \\
\hline & & & & PFS (mo) & $\begin{array}{l}\text { OS } \\
\text { (mo) }\end{array}$ & $\begin{array}{l}\text { ORR } \\
\text { (\%) }\end{array}$ & Ref \\
\hline NP28673 & II & Alectinib, single arm & Pretreated with crizotinib & 8.9 & 26 & 51 & 49 \\
\hline NP2876I & II & Alectinib, single arm & Pretreated with crizotinib & 8 & 22.7 & 52 & 50 \\
\hline ALUR & III & $\begin{array}{l}\text { Alectinib vs } \\
\text { chemotherapy }\end{array}$ & $\begin{array}{l}\text { Pretreated with platinum-based che- } \\
\text { motherapy and crizotinib }\end{array}$ & $\begin{array}{l}7 . I \text { vs } 1.6 * H R \quad 0.32 \text {, } \\
P<0.00 I\end{array}$ & $\begin{array}{l}12.6 \text { vs } \\
\mathrm{NE}\end{array}$ & 38 vs 3 & 22 \\
\hline ALEX & III & Alectinib vs crizotinib & First-line (treatment naïve) & $\begin{array}{l}34.8 \text { vs } 10.9, \mathrm{HR} \\
0.43, \mathrm{P}<0.00 \mathrm{I}\end{array}$ & - & 83 vs 75 & 24,54 \\
\hline ALEX J & III & $\begin{array}{l}\text { Alectinib }(300 \mathrm{mg}) \text { vs } \\
\text { crizotinib }\end{array}$ & ALK-inhibitor naïve & $\begin{array}{l}25.9 \text { vs } 10.2, \mathrm{HR} \\
0.38, \mathrm{P}<0.000 \mathrm{I}\end{array}$ & - & 85 vs 70 & 23,52 \\
\hline
\end{tabular}

Note: *Independent review committee.

Abbreviations: PFS, Progression-free survival; OS, Overall survival; ORR, Objective Response Rate; mo, months vs, versus; NE, not estimable.

(95\% CI 6.4, 15.7 in the crizotinib group (HR 0.40 [95\% CI $0.19,0.87]) .{ }^{23}$ Patients treated with alectinib obtained an ORR of $85 \%$ versus $70 \%$ for those receiving crizotinib. ${ }^{23}$ Updated data from the J-ALEX study showed median PFS of 25.9 months (95\% CI 20.3, not estimable) with alectinib and 10.2 months $(95 \%$ CI 8.3, 12.0) with crizotinib (HR 0.38 [95\% CI $0.26,0.55, \mathrm{P}<0.0001)] .{ }^{52}$ In the J-ALEX study, in 164 patients without brain metastasis at baseline, alectinib prevented CNS progression with a HR of 0.19 (95\% CI $0.07,0.53)$ compared to crizotinib. The same occurred for the 43 patients with brain metastasis at baseline, who had a lower risk for CNS progression with alectinib compared to crizotinib ( $\mathrm{HR}=0.51,95 \% \mathrm{CI}$ $0.16,1.64) .^{52}$

The Phase III ALEX trial was conducted in non-Asiatic and Asiatic population. ${ }^{24} \mathrm{~A}$ total of $303 \mathrm{ALK}+$ treatment-na ive NSCLC patients were treated with either $600 \mathrm{mg}$ of alectinib twice daily or $250 \mathrm{mg}$ of crizotinib twice daily. The investigator-assessed median PFS was not reached $(95 \% \mathrm{CI}$ 17.7, not estimable) with alectinib versus 11.1 months $(95 \%$ CI 9.1, 13.1) with crizotinib (HR 0.47 [95\% CI 0.34, 0.65], $\mathrm{P}<0.001$ (Table 1). ${ }^{24}$ Median PFS as assessed by an IRC was longer with alectinib compared to crizotinb (25.7 months [95\% CI 19.9, not estimable) versus 10.4 months [95\% CI $7.7,14.6], \mathrm{HR}, 0.50$ [95\% CI $0.36,0.70], \mathrm{P}<0.001) .{ }^{24}$ No statistically significant differences occurred in terms of responses with a response rate of $83 \%(95 \%$ CI 76,88$)$ and $75 \%(95 \%$ CI 68,82$)$ for alectinib and crizotinib, respectively $(\mathrm{P}=0.09)$ (Table 1). ${ }^{24}$ Finally, in the ALEX study, patients with measurable baseline brain metastases and prior radiotherapy had a CNS ORR of $85.7 \%$ with alectinib and $71.4 \%$ with crizotinib. ${ }^{53}$ For those patients who had not received prior radiotherapy, the CNS ORR was $78.6 \%$ and $40.0 \%$ for alectinib and crizotinib, respectively. Importantly, alectinib significantly delayed CNS progression, independent of the existence or not of baseline brain metastases or the treatment or not with prior radiotherapy. ${ }^{53}$ Patients with baseline brain metastases had median PFS of 24.7 months (95\% CI 9.2, not estimable) with alectinib compared to 7.4 months ( $95 \%$ CI 6.6, 9.6) for crizotinib ( $\mathrm{HR}=0.35,95 \%$ CI $0.22,0.56) .{ }^{54}$ With a longer follow-up, median PFS of 34.8 months $(95 \%$ CI 17.7, not estimable) for alectinib versus 10.9 months $(95 \%$ CI 9.1, 12.9) for crizotinib (HR $0.43,95 \%$ CI $0.32,0.58$ ) was reported. ${ }^{54}$ Patients treated with alectinib had a longer median DoR compared to crizotinib (33.1 [95\% CI 31.3, not estimable] versus 11.1 months [95\% CI 7.9, 13.0], HR 0.36 [95\% CI $0.24 ; 0.53]){ }^{24,54}$ These updated data consolidate alectinib as the standard-of-care for first-line treatment of ALK+ NSCLC patients. Based on the data of the ALEX study, on 7 November 2017, FDA approved alectinib for the first-line treatment of patients with ALK+ NSCLC. One month later, on 21 December 2017, alectinib was also EMA approved.

Alectinib is a well-tolerated drug. The most frequent of any grade adverse events are gastrointestinal disorders, hepatobiliary disorders, edema, rash, myalgia, anemia and increased body weight. ${ }^{32}$ This information is derived from a pooled analysis of three alectinib trials (ALEX, NP28673 and NP28761). ${ }^{32}$ Adverse events of grade more than 3 occurred only in $<4 \%$ of the patients. ${ }^{32}$ Liver function disorders are the most common grade $\geq 3$ adverse events, that are transient and resolved, when alectinib is interrupted or when it is given in a lower dose. Grade 1-2 bradycardia has been reported in almost $9 \%$ of patients receiving alectinib. Interstitial lung disease (ILD) is uncommon, but grade $\geq 3$ ILD which led to treatment discontinuation, occurred in one patient. Elevated blood creatinine phosphokinase (CPK) and anemia are also 
common grade $\geq 3$ adverse events. For the above reasons, liver function, heart rate and blood pressure, pulmonary symptoms, CPK blood levels and anemia should be monitored in patients who are treated with alectinib.

\section{Mechanisms of resistance to alectinib}

As happens with all targeted therapies, resistance inevitably emerges after treatment with alectinib or other ALK inhibitors. ALK resistant mutations appear to be the main mechanism of resistance to second-generation ALK inhibitors. We have combined data available from three previous publications ${ }^{14,35,55}$ to summarize the activity of alectinib and other ALK inhibitors against various resistant mutations (Table 2). ALK I1171 mutations are reported to be the second (after $A L K$ G1202R) most common $A L K$ resistance mutations in post-alectinib specimens. Alectinib is also inactive against L1196M, V1180L and T1151Tins mutations (Table 2).

Maintained mitogen-activated protein kinase (MAPK) activation through alternate kinases, including EGFR, KIT, Src, insulin growth factor 1 or the src homology 2 domaincontaining phosphatase $2^{56}$ has been also described as a mechanism of resistance to ALK inhibitors. ${ }^{57-60}$ We have found that $K R A S$ wild-type copy number gain decreased of the dual specificity phosphatase 6 phosphatase reactivates the MAPK pathway in the presence of ALK inhibitors and therefore leads to tumor resistance. ${ }^{61}$ To this end, a clinical trial with the combination of alectinib with the MEK inhibitor cobimetinib is ongoing in ALK+ NSCLC patients (Table 3).

\section{Discussion - sequencing of treatment for ALK+ NSCLC patients}

A main point of discussion for ALK+ NSCLC patients is the optimal sequencing of the available agents. More precise diagnosis for identifying the $A L K$ fusion partner is also of great relevance, considering that fusion partners affect the sensitivity to different ALK inhibitors. ${ }^{62}$ Therefore, in situ hybridization (FISH) or immunohistochemistry are not enough for the accurate diagnosis of ALK+ NSCLC patients. Next-generation sequencing technologies must come to the forefront of clinical diagnostics for the clinicians to know the fusion partner. ${ }^{62}$ On the other hand, next-generation sequencing platforms allow us to know whether the resistance comes from acquired resistant mutations or from activation of bypass signaling pathways. This is important for selecting next therapeutic options. The activation of bypass signaling pathways may require a tissue re-biopsy as in circulating-free
DNA alterations such as small cell transformation or epithelial-mesenchymal transition cannot be easily defined. ${ }^{63}$ Therefore, liquid biopsies serve for the detection of ALK

Table 2 Half-maximal inhibitory concentrations (IC50) of first-, second- and third-generation ALK inhibitors on mutant EML4-ALK (data derived from ${ }^{14,35,55}$ )

\begin{tabular}{|c|c|c|c|c|c|}
\hline $\begin{array}{l}\text { ALK resis- } \\
\text { tant } \\
\text { mutations }\end{array}$ & $\begin{array}{l}\text { Criz- } \\
\text { otinib }\end{array}$ & $\begin{array}{l}\text { Cerit- } \\
\text { inib }\end{array}$ & $\begin{array}{l}\text { Alec- } \\
\text { tinib }\end{array}$ & $\begin{array}{l}\text { Briga- } \\
\text { tinib }\end{array}$ & $\begin{array}{l}\text { Lorla- } \\
\text { tinib }\end{array}$ \\
\hline \multicolumn{6}{|l|}{ GI269A } \\
\hline \multicolumn{6}{|l|}{ EI2IOK } \\
\hline SI 206Y & & & & & ND \\
\hline SI $206 \mathrm{~F}$ & & & & & ND \\
\hline \multicolumn{6}{|l|}{ DI $203 N$} \\
\hline \multicolumn{6}{|l|}{ GI202del } \\
\hline \multicolumn{6}{|l|}{ GI202R } \\
\hline \multicolumn{6}{|l|}{ LII96M } \\
\hline VII80L & & & & & ND \\
\hline FII74C & & & & & ND \\
\hline FII74L & & & & & ND \\
\hline FII74V & & & & & ND \\
\hline \multicolumn{6}{|l|}{ CII56Y } \\
\hline \multicolumn{6}{|l|}{ IIIIIN } \\
\hline \multicolumn{6}{|l|}{ IIITIS } \\
\hline \multicolumn{6}{|l|}{ III7IT } \\
\hline \multicolumn{6}{|l|}{ FII74C } \\
\hline LII I52R & ND & & & & ND \\
\hline LII52P & & & & & ND \\
\hline \multicolumn{6}{|l|}{ LII } \\
\hline TII5ITins & & & & & ND \\
\hline \multicolumn{6}{|l|}{$\begin{array}{l}\text { DI203N } \\
+ \text { FII } 74 C\end{array}$} \\
\hline \multirow[t]{4}{*}{$\begin{array}{l}\text { DI203N } \\
+E I 2 I 0 K\end{array}$} & ND & & & & \\
\hline & & & \multicolumn{3}{|c|}{$\mathrm{IC} 50 \leq 50 \mathrm{nmol} / \mathrm{L}$} \\
\hline & & & \multicolumn{3}{|c|}{$>50,<200 \mathrm{nmol} / \mathrm{L}$} \\
\hline & & & \multicolumn{3}{|c|}{$\geq 200 \mathrm{nmol} / \mathrm{L}$} \\
\hline
\end{tabular}

Abbreviation: ND, not determined. 
Table 3 Ongoing clinical trials with alectinib

\begin{tabular}{|c|c|c|c|}
\hline $\begin{array}{l}\text { ClinicalTrials. } \\
\text { gov Identifier }\end{array}$ & Phase & Treatment & Objective \\
\hline NCT03 I94893 & $\begin{array}{l}\text { III, } \\
\text { open }\end{array}$ & Alectinib, crizotinib & $\begin{array}{l}\text { To provide continued treatment with alectinib or crizotinib as } \\
\text { applicable to patients with ALK- or RET-positive cancer who were } \\
\text { previously enrolled in any Roche-sponsored alectinib study and who } \\
\text { are deriving continued clinical benefit from alectinib or crizotinib in } \\
\text { the parent trial at the time of parent trial closure }\end{array}$ \\
\hline- & $\begin{array}{l}\text { II, open } \\
\text { (Japan) }\end{array}$ & Alectinib & $\begin{array}{l}\text { To evaluate the efficacy and safety of alectinib in patients with rare } \\
\text { cancer harboring ALK alterations }\end{array}$ \\
\hline NCT03596866 & $\begin{array}{l}\text { III, } \\
\text { planned }\end{array}$ & Alectinib versus brigatinib & $\begin{array}{l}\text { To compare the efficacy of brigatinib versus alectinib in participants } \\
\text { with ALK + locally advanced or metastatic NSCLC who have pro- } \\
\text { gressed on crizotinib }\end{array}$ \\
\hline NCT03456076 & $\begin{array}{l}\text { III, } \\
\text { open }\end{array}$ & $\begin{array}{l}\text { Alectinib versus platinum-based chemother- } \\
\text { apy (adjuvant) }\end{array}$ & $\begin{array}{l}\text { To evaluate the efficacy and safety of adjuvant alectinib versus } \\
\text { adjuvant platinum-based chemotherapy in patients with completely } \\
\text { resected stage IB (tumors equal to or larger than } 4 \mathrm{~cm} \text { ) to stage IIIA } \\
\text { ALK+ NSCLC }\end{array}$ \\
\hline NCT03445000 & II, open & Alectinib & $\begin{array}{l}\text { To investigate the efficacy of alectinib in patients with advanced } \\
\text { stage RET-rearranged NSCLC, treated with at least one platinum- } \\
\text { based systemic chemotherapy regimen }\end{array}$ \\
\hline NCT03202940 & $\begin{array}{l}\text { I/II, } \\
\text { open }\end{array}$ & Alectinib plus cobimetinib & $\begin{array}{l}\text { To study the combination of alectinib and cobimetinib as a possible } \\
\text { treatment for ALK+ NSCLC }\end{array}$ \\
\hline NCT03779I9I & $\begin{array}{l}\text { II, } \\
\text { planned }\end{array}$ & Alectinib plus bevacizumab & $\begin{array}{l}\text { To assess alectinib plus bevacizumab in untreated and previously } \\
\text { treated patients with advanced or metastatic non-squamous ALK+ } \\
\text { NSCLC }\end{array}$ \\
\hline NCT0252I 05 I & $\begin{array}{l}\text { I/II, } \\
\text { open }\end{array}$ & Alectinib plus bevacizumab & $\begin{array}{l}\text { To evaluate the safety and tolerability of alectinib and bevacizumab } \\
\text { in patients with ALK+ NSCLC }\end{array}$ \\
\hline $\begin{array}{l}\text { NCT0209 I I } 4 \text { I } \\
\text { (My pathway) }\end{array}$ & II, open & $\begin{array}{l}\text { Alectinib, atezolizumab, vemurafenib/cobi- } \\
\text { metinib, erlotinib, pertuzumab/trastuzumab, } \\
\text { vismodegib }\end{array}$ & $\begin{array}{l}\text { To evaluate trastuzumab/pertuzumab, erlotinib, vemurafenib/cobi- } \\
\text { metinib, vismodegib, alectinib and atezolizumab in patients who } \\
\text { have advanced solid tumors with mutations or gene expression } \\
\text { abnormalities predictive of response to one of these agents }\end{array}$ \\
\hline
\end{tabular}

Abbreviations: NSCLC, non-small cell lung cancer; ALK, anapestic lymphoma kinase.

acquired mutations, but if resistant mutations are not detected, then a tissue biopsy is necessary. ${ }^{63}$

Alectinib together with crizotinib and ceritinib are approved as first-line therapies for ALK+ NSCLC patients. Brigatinib is expected to gain soon first-line approval. We still do not know whether median PFS with brigatinib will be longer than what has been achieved with alectinib in the firstline setting. ${ }^{25}$ Lorlatinib is approved for ALK+ NSCLC patients after progression to 1 or 2 prior lines of ALK TKIs. The ongoing clinical trials are comparing the secondgeneration ALK TKIs with crizotinib in the first-line setting and therefore we speculate that all of them will be positive studies. However, the key question is what the correct secondline therapy after a second-generation ALK inhibitor is? If this is the third-generation inhibitor, lorlatinib, then what comes next? Whether the combination of chemotherapy with immunotherapy is an option, is still debatable? In the subgroup analysis of the IMpower150 study, the combination of carboplatin, paclitaxel, bevacizumab and atezolizumab improved PFS compared to chemotherapy plus bevacizumab alone in ALK+ NSCLC patients. ${ }^{64}$ Overall, only 34 ALK+ patients were included in the study and therefore the results of this subgroup analysis cannot be conclusive. Furthermore, many doubts have been raised on the design of this study, as well as on the way that the results were presented, especially because they exclude the comparison of carboplatin, paclitaxel, bevacizumab, and atezolizumab versus carboplatin, paclitaxel and atezolizumab. ${ }^{65,66}$ Therefore, the IMpower150 study did not address the question whether vascular endothelial growth factor blockade enhances the efficacy of immunotherapy. ${ }^{64,65}$

Crizotinib probably will have no role in the treatment of $\mathrm{ALK}+$ patients in the future. May be at the time that lorlatinib will come in the first-line setting, crizotinib will become useful again as it overcomes some of the lorlatinib-resistant mutations, like the double C1156Y-L1198F. ${ }^{67}$ Right now, 
alectinib and ceritinib are the only second-generation ALK inhibitors with CNS activity, approved in the first-line setting. Ceritinib is a very potent ALK inhibitor but with serious toxicity issues, at least when it was given at the initial approved fasting dose of $750 \mathrm{mg}$ daily. Now, $450 \mathrm{mg}$ of ceritinib given with food is the new FDA and EMA approved regimen, and ceritinib becomes again a very relevant compound for the first-line therapy of ALK+ NSCLC patients. ${ }^{68}$ Brigatinib, which we anticipate that it will be soon approved for the same indication, has shown the longest intracranial PFS of 18 months in the $90-180 \mathrm{mg}$ cohort. ${ }^{69}$ Therefore, it is possible that soon, neither alectinib nor ceritinib, but brigatinib will be the ALK TKI to be used for the first-line therapy of ALK+ NSCLC patients. Lorlatinib, due to each side effects, is mostly preferred after two second-generation (alectinib and ceritinib, or alectinib and brigatinb) ALK TKIs. It will soon become the second ALK TKI to be used when medical oncologists are familiar with the management of the side effects of lorlatinib. ${ }^{70,71}$ In the case that an ALK+ NSCLC patient progresses to several ALK TKIs, a chemotherapy regimen, like carboplatin with pemetrexed with or without bevacizumab may control the disease for a certain period and give space for ALK TKIs to regain activity after a "targeted therapy break".

\section{Conclusion}

We searched the Citeline Pharma Intelligence (https://cite line.informa.com/trials/results) for clinical trials with alectinib, that are open or ongoing (Table 3). A Phase III clinical trial plans to compare alectinib versus brigatinib for ALK+ NSCLC patients who have progressed to crizotinib. Alectinib is currently under comparison with adjuvant platinum-based chemotherapy for stage IB-IIIA completely resected ALK+ NSCLC patients. Two studies are planned to test the efficacy of alectinib in combination with bevacizumab in ALK+ NSCLC patients. Considering its efficacy and tolerability, alectinib is the best first-line approach for ALK+ NSCLC patients, especially those with CNS metastasis at the time of the diagnosis. Alectinib is an important treatment option for ALK+ NSCLC patients who have progressed to crizotinib.

\section{Acknowledgments}

Work in Dr Rosell's laboratory is partially supported by a grant from La Caixa Foundation, an Instituto de Salud Carlos III grant (RESPONSE, PIE16/00011), a Marie Skłodowska-Curie Innovative Training Networks European Grant (ELBA No 765492) and a Spanish Association
Against Cancer (AECC) grant (PROYE18012ROSE). The Funders had no role in the design and conduct of the study; collection, management, analysis and interpretation of the data; preparation, review or approval of the manuscript; and decision to submit the manuscript for publication.

\section{Disclosure}

The authors report no conflicts of interest in this work.

\section{References}

1. Rosell R, Bivona TG, Karachaliou N. Genetics and biomarkers in personalisation of lung cancer treatment. Lancet. 2013;382 (9893):720-731. doi:10.1016/S0140-6736(13)61715-8

2. Rosell R, Karachaliou N. Large-scale screening for somatic mutations in lung cancer. Lancet. 2016;387(10026):1354-1356. doi:10.1016/S0140-6736(15)01125-3

3. Morris SW, Kirstein MN, Valentine MB, et al. Fusion of a kinase gene, ALK, to a nucleolar protein gene, NPM, in non-Hodgkin's lymphoma. Science. 1994;263(5151):1281-1284.

4. Chiarle R, Voena C, Ambrogio C, Piva R, Inghirami G. The anaplastic lymphoma kinase in the pathogenesis of cancer. Nat Rev Cancer. 2008;8(1):11-23. doi:10.1038/nrc2291

5. Webb TR, Slavish J, George RE, et al. Anaplastic lymphoma kinase: role in cancer pathogenesis and small-molecule inhibitor development for therapy. Expert Rev Anticancer Ther. 2009;9(3):331-356. doi:10.1586/14737140.9.3.331

6. Horn L, Pao W. EML4-ALK: honing in on a new target in non-smallcell lung cancer. J Clin Oncol. 2009;27(26):4232-4235. doi:10.1200/ JCO.2009.23.6661

7. Soda M, Choi YL, Enomoto M, et al. Identification of the transforming EML4-ALK fusion gene in non-small-cell lung cancer. Nature. 2007;448(7153):561-566. doi:10.1038/nature05945

8. Rikova K, Guo A, Zeng Q, et al. Global survey of phosphotyrosine signaling identifies oncogenic kinases in lung cancer. Cell. 2007;131 (6):1190-1203. doi:10.1016/j.cell.2007.11.025

9. Passaro A, Lazzari C, Karachaliou N, et al. Personalized treatment in advanced ALK-positive non-small cell lung cancer: from bench to clinical practice. Onco Targets Ther. 2016;9:6361-6376. doi:10.2147/ OTT.S98347

10. Sasaki T, Rodig SJ, Chirieac LR, Janne PA. The biology and treatment of EML4-ALK non-small cell lung cancer. Eur $J$ Cancer. 2010;46(10):1773-1780. doi:10.1016/j.ejca.2010.04.002

11. Kwak EL, Bang YJ, Camidge DR, et al. Anaplastic lymphoma kinase inhibition in non-small-cell lung cancer. $N$ Engl J Med. 2010;363 (18):1693-1703. doi:10.1056/NEJMoa1006448

12. Shaw AT, Kim DW, Nakagawa K, et al. Crizotinib versus chemotherapy in advanced ALK-positive lung cancer. N Engl J Med. 2013;368 (25):2385-2394. doi:10.1056/NEJMoa1214886

13. Solomon BJ, Mok T, Kim DW, et al. First-line crizotinib versus chemotherapy in ALK-positive lung cancer. $N$ Engl J Med. 2014;371(23):2167-2177. doi:10.1056/NEJMoa1408440

14. Gainor JF, Dardaei L, Yoda S, et al. Molecular mechanisms of resistance to first- and second-generation ALK inhibitors in ALK-rearranged lung cancer. Cancer Discov. 2016;6 (10):1118-1133. doi:10.1158/2159-8290.CD-16-0596

15. Karachaliou N, Rosell R. Systemic treatment in EGFR-ALK NSCLC patients: second line therapy and beyond. Cancer Biol Med. 2014;11 (3):173-181. doi:10.7497/j.issn.2095-3941.2014.03.003

16. Karachaliou N, Rosell R, Morales-Espinosa D, Viteri S. Systemic treatment in EGFR-ALK NSCLC patients: second line therapy and beyond. Expert Rev Anticancer Ther. 2014;14(7):807-815. doi:10.1586/14737140.2014.896210 
17. Gainor JF, Sherman CA, Willoughby K, et al. Alectinib salvages CNS relapses in ALK-positive lung cancer patients previously treated with crizotinib and ceritinib. J Thorac Oncol. 2015;10(2):232-236. doi: $10.1097 /$ JTO.0000000000000455

18. Pacheco JM, Gao D, Smith D, et al. Natural history and factors associated with overall survival in stage IV ALK-rearranged nonsmall cell lung cancer. $J$ Thorac Oncol. 2019;14(4):691-700. doi:10.1016/j.jtho.2018.12.014

19. Shaw AT, Kim DW, Mehra R, et al. Ceritinib in ALK-rearranged non-small-cell lung cancer. $N$ Engl J Med. 2014;370(13):1189-1197. doi:10.1056/NEJMoa1311107

20. Soria JC, Tan DSW, Chiari R, et al. First-line ceritinib versus platinum-based chemotherapy in advanced ALK-rearranged non-small-cell lung cancer (ASCEND-4): a randomised, open-label, phase 3 study. Lancet. 2017;389(10072):917-929. doi:10.1016/ S0140-6736(17)30123-X

21. Shaw AT, Kim TM, Crino L, et al. Ceritinib versus chemotherapy in patients with ALK-rearranged non-small-cell lung cancer previously given chemotherapy and crizotinib (ASCEND-5): a randomised, controlled, open-label, phase 3 trial. Lancet Oncol. 2017;18(7):874-886. doi:10.1016/S1470-2045(17)30339-X

22. Novello S, Mazières J, Oh I-J, et al. Alectinib versus chemotherapy in crizotinib-pretreated anaplastic lymphoma kinase (ALK)-positive non-small-cell lung cancer: results from the phase III ALUR study. Ann Oncol. 2018;29(6):1409-1416. doi:10.1093/annonc/mdy121

23. Hida T, Nokihara $H$, Kondo $M$, et al. Alectinib versus crizotinib in patients with ALK-positive non-small-cell lung cancer (J-ALEX): an open-label, randomised phase 3 trial. Lancet. 2017;390 (10089):29-39. doi:10.1016/S0140-6736(17)30565-2

24. Peters S, Camidge DR, Shaw AT, et al. Alectinib versus crizotinib in untreated ALK-positive non-small-cell lung cancer. $N$ Engl $J$ Med. 2017;377(9):829-838. doi:10.1056/NEJMoa1704795

25. Camidge DR, Kim HR, Ahn MJ, et al. Brigatinib versus crizotinib in ALK-positive non-small-cell lung cancer. $N$ Engl J Med. 2018;379 (21):2027-2039. doi:10.1056/NEJMoa1810171

26. Shaw AT, Felip E, Bauer TM, et al. Lorlatinib in non-small-cell lung cancer with ALK or ROS1 rearrangement: an international, multicentre, open-label, single-arm first-in-man phase 1 trial. Lancet Oncol. 2017;18 (12):1590-1599. doi:10.1016/S1470-2045(17)30680-0

27. Solomon B, Shaw A, Ou S, et al. OA 05.06 phase 2 study of lorlatinib in patients with advanced $\mathrm{ALK}^{+} / \mathrm{ROS}^{+}$non-small-cell lung cancer. $J$ Thoracic Oncol. 2017;12(11):S1756. doi:10.1016/j. jtho.2016.09.002

28. Horn L, Infante JR, Reckamp KL, et al. Ensartinib (X-396) in ALK-positive non-small cell lung cancer: results from a first-inhuman phase I/II, multicenter study. Clin Cancer Res. 2018;24 (12):2771-2779. doi:10.1158/1078-0432.CCR-17-2398

29. Drilon A, Ou SI, Cho BC, et al. Repotrectinib (TPX-0005) is a next-generation ROS1/TRK/ALK inhibitor that potently inhibits ROS1/TRK/ALK solvent- front mutations. Cancer Discov. 2018;8 (10):1227-1236. doi:10.1158/2159-8290.CD-18-0484

30. Sullivan I, Planchard D. ALK inhibitors in non-small cell lung cancer: the latest evidence and developments. Ther Adv Med Oncol. 2016;8(1):32-47. doi:10.1177/1758834015617355

31. Shaw AT, Varghese AM, Solomon BJ, et al. Pemetrexed-based chemotherapy in patients with advanced, ALK-positive non-small cell lung cancer. Ann Oncol. 2013;24(1):59-66. doi:10.1093/annonc/ mds 242

32. Paik J, Dhillon S. Alectinib: a review in advanced, ALK-positive NSCLC. Drugs. 2018;78(12):1247-1257. doi:10.1007/s40265-0180952-0

33. Sakamoto H, Tsukaguchi T, Hiroshima S, et al. CH5424802, a selective ALK inhibitor capable of blocking the resistant gatekeeper mutant. Cancer Cell. 2011;19(5):679-690. doi:10.1016/j. ccr.2011.04.004
34. Kodama T, Tsukaguchi T, Yoshida M, Kondoh O, Sakamoto H. Selective ALK inhibitor alectinib with potent antitumor activity in models of crizotinib resistance. Cancer Lett. 2014;351(2):215-221. doi:10.1016/j.canlet.2014.05.020

35. Yoda S, Lin JJ, Lawrence MS, et al. Sequential ALK Inhibitors Can Select for Lorlatinib-Resistant Compound ALK Mutations in ALK-Positive Lung Cancer. Cancer Discov. 2018;8(6):714-729. doi:10.1158/2159-8290.CD-17-1256

36. Kodama T, Tsukaguchi T, Satoh Y, et al. Alectinib shows potent antitumor activity against RET-rearranged non-small cell lung cancer. Mol Cancer Ther. 2014;13(12):2910-2918. doi:10.1158/ 1535-7163.MCT-14-0274

37. Kohno T, Ichikawa H, Totoki Y, et al. KIF5B-RET fusions in lung adenocarcinoma. Nat Med. 2012;18(3):375-377. doi:10.1038/nm.2644

38. Gautschi O, Milia J, Filleron T, et al. Targeting RET in patients with RET-rearranged lung cancers: results from the global, multicenter RET registry. J Clin Oncol. 2017;35(13):1403-1410. doi:10.1200/ JCO.2016.70.9352

39. Pirker R, Filipits M. Alectinib in RET-rearranged non-small cell lung cancer-another progress in precision medicine? Transl Lung Cancer Res. 2015;4(6):797-800. doi:10.3978/j.issn.2218-6751.2015.03.08

40. Drilon AE, Subbiah V, Oxnard GR, et al. A phase 1 study of LOXO-292, a potent and highly selective RET inhibitor, in patients with RET-altered cancers. J Clin Oncol. 2018;36(15_suppl):102. doi:10.1200/JCO.2018.36.15_suppl.102

41. Subbiah V, Gainor JF, Rahal R, et al. Precision targeted therapy with BLU-667 for RET-driven cancers. Cancer Discov. 2018;8 (7):836-849. doi:10.1158/2159-8290.CD-18-0338

42. BLU-667 targets RET-altered cancers. Cancer Discov. 2018;8(6): OF8. doi:10.1158/2159-8290.CD-NB2018-050

43. Drilon A, Rekhtman N, Arcila M, et al. Cabozantinib in patients with advanced RET-rearranged non-small-cell lung cancer: an open-label, single-centre, phase 2, single-arm trial. Lancet Oncol. 2016;17 (12):1653-1660. doi:10.1016/S1470-2045(16)30562-9

44. Gadgeel SM, Gandhi L, Riely GJ, et al. Safety and activity of alectinib against systemic disease and brain metastases in patients with crizotinib-resistant ALK-rearranged non-small-cell lung cancer (AF-002JG): results from the dose-finding portion of a phase $1 / 2$ study. Lancet Oncol. 2014;15(10):1119-1128. doi:10.1016/S14702045(14)70362-6

45. Seto T, Kiura K, Nishio M, et al. CH5424802 (RO5424802) for patients with ALK-rearranged advanced non-small-cell lung cancer (AF-001JP study): a single-arm, open-label, phase 1-2 study. Lancet Oncol. 2013;14(7):590-598. doi:10.1016/S1470-2045(13)70142-6

46. Tamura T, Kiura K, Seto T, et al. Three-year follow-up of an alectinib phase I/II study in ALK-positive non-small-cell lung cancer: AF-001JP. J Clin Oncol. 2017;35(14):1515-1521. doi:10.1200/JCO.2016.70.5749

47. Ou SH, Ahn JS, De Petris L, et al. Alectinib in crizotinib-refractory ALK-rearranged non-small-cell lung cancer: a phase II global study. J Clin Oncol. 2016;34(7):661-668. doi:10.1200/jco.2016.34.4_suppl.661

48. Shaw AT, Gandhi L, Gadgeel S, et al. Alectinib in ALK-positive, crizotinib-resistant, non-small-cell lung cancer: a single-group, multicentre, phase 2 trial. Lancet Oncol. 2016;17(2):234-242. doi:10.1016/S1470-2045(15)00488-X

49. Zeaiter A, Dingemans A-MC, Balas B, et al. Updated efficacy and safety from the global phase II NP28673 study of alectinib in patients (pts) with previously treated ALK+ non-small-cell lung cancer (NSCLC). Ann of Oncology. 2016;27(suppl_6). doi:10.1093/annonc/mdw141.

50. Camidge DR, Gadgeel S, Ou S-H, et al. MA07.02 updated efficacy and safety data from the phase 2 NP28761 study of alectinib in ALK-positive non-small-cell lung cancer. $J$ Thoracic Oncol. 2017;12(1):S378. doi:10.1016/j.jtho.2016.09.002

51. Yang JC, Ou SI, De Petris L, et al. Pooled systemic efficacy and safety data from the pivotal phase II studies (NP28673 and NP28761) of alectinib in ALK-positive non-small cell lung cancer. $J$ Thorac Oncol. 2017;12(10):1552-1560. doi:10.1016/j.jtho.2017.06.070 
52. Takiguchi Y, Hida T, Nokihara H, et al. Updated efficacy and safety of the j-alex study comparing alectinib (ALC) with crizotinib (CRZ) in ALK-inhibitor naïve ALK fusion positive non-small cell lung cancer (ALK+ NSCLC). Journal of Clinical Oncology2017; 35 (15_suppl): 9064.

53. Gadgeel S, Peters S, Mok T, et al. Alectinib versus crizotinib in treatment-naive anaplastic lymphoma kinase-positive (ALK+) non-smallcell lung cancer: CNS efficacy results from the ALEX study. Ann Oncol. 2018;29(11):2214-2222. doi:10.1093/annonc/mdy405

54. Camidge DR, Peters S, Mok T, et al. Updated efficacy and safety data from the global phase III ALEX study of alectinib (ALC) vs crizotinib (CZ) in untreated advanced ALK+ NSCLC. Journal of Clinical Oncology2018; 36(15_suppl): 9043.

55. Zhang S, Anjum R, Squillace R, et al. The potent ALK inhibitor brigatinib (AP26113) overcomes mechanisms of resistance to firstand second-generation ALK inhibitors in preclinical models. Clin Cancer Res. 2016;22(22):5527-5538. doi:10.1158/1078-0432.CCR16-0569

56. Karachaliou N, Cardona AF, Bracht JWP, et al. Integrin-linked kinase (ILK) and src homology 2 domain-containing phosphatase 2 (SHP2): novel targets in EGFR-mutation positive non-small cell lung cancer (NSCLC). EBioMedicine. 2019;39:207-214. doi:10.1016/j. ebiom.2018.11.036

57. Katayama R, Shaw AT, Khan TM, et al. Mechanisms of acquired crizotinib resistance in ALK-rearranged lung Cancers. Sci Transl Med. 2012;4(120):120ra117. doi:10.1126/scitranslmed.3003316

58. Crystal AS, Shaw AT, Sequist LV, et al. Patient-derived models of acquired resistance can identify effective drug combinations for cancer. Science. 2014;346(6216):1480-1486. doi:10.1126/science.1254721

59. Lovly CM, McDonald NT, Chen H, et al. Rationale for co-targeting IGF-1R and ALK in ALK fusion-positive lung cancer. Nat Med. 2014;20(9):1027-1034. doi:10.1038/nm.3667

60. Dardaei L, Wang HQ, Singh M, et al. SHP2 inhibition restores sensitivity in ALK-rearranged non-small-cell lung cancer resistant to ALK inhibitors. Nat Med. 2018;24(4):512-517. doi:10.1038/nm.4497

61. Hrustanovic G, Olivas V, Pazarentzos E, et al. RAS-MAPK dependence underlies a rational polytherapy strategy in EML4-ALK-positive lung cancer. Nat Med. 2015;21(9):1038-1047. doi:10.1038/nm.3930
62. Childress MA, Himmelberg SM, Chen H, Deng W, Davies MA, Lovly CM. ALK fusion partners impact response to ALK inhibition: differential effects on sensitivity, cellular phenotypes, and biochemical properties. Mol Cancer Res. 2018;16(11):1724-1736. doi:10.1158/1541-7786.MCR-18-0171

63. Ou SI, Lee TK, Young L, et al. Dual occurrence of ALK G1202R solvent front mutation and small cell lung cancer transformation as resistance mechanisms to second generation ALK inhibitors without prior exposure to crizotinib. Pitfall of Solely Relying on Liquid Re-Biopsy? Lung Cancer. 2017;106:110-114. doi:10.1016/j.lungcan.2017.02.005

64. Socinski MA, Jotte RM, Cappuzzo F, et al. Atezolizumab for first-line treatment of metastatic nonsquamous NSCLC. $N$ Engl $J$ Med. 2018;378(24):2288-2301. doi:10.1056/NEJMoa1716948

65. Mountzios G, Calles A, Addeo A. Atezolizumab treatment of nonsquamous NSCLC. $N$ Engl J Med. 2018;379(12):1187. doi:10.1056/ NEJMc1809195

66. Ashraf N. Atezolizumab treatment of nonsquamous NSCLC. $N$ Engl J Med. 2018;379(12):1187-1188. doi:10.1056/NEJMc1809 195

67. Shaw AT, Friboulet L, Leshchiner I, et al. Resensitization to crizotinib by the lorlatinib ALK resistance mutation L1198F. N Engl J Med. 2016;374(1):54-61. doi:10.1056/NEJMoa1508887

68. Cho BC, Obermannová R, Bearz A, et al. OA 05.07 efficacy and updated safety of ceritinib (450 mg or $600 \mathrm{mg}$ ) with low-fat meal vs $750 \mathrm{mg}$ fasted in ALK+ metastatic NSCLC. J Thoracic Oncol. 2017;12(11):S1757. doi:10.1016/j.jtho.2016.09.002

69. Camidge DR, Kim DW, Tiseo M, et al. Exploratory analysis of brigatinib activity in patients with anaplastic lymphoma kinase-positive non-small-cell lung cancer and brain metastases in two clinical trials. J Clin Oncol. 2018;36(26):2693-2701. doi:10.1200/JCO.2017.77.5841

70. Solomon BJ, Besse B, Bauer TM, et al. Lorlatinib in patients with ALK-positive non-small-cell lung cancer: results from a global phase 2 study. Lancet Oncol. 2018;19(12):1654-1667. doi:10.1016/S14702045(18)30649-1

71. Akamine T, Toyokawa G, Tagawa T, Seto T. Spotlight on lorlatinib and its potential in the treatment of NSCLC: the evidence to date. Onco Targets Ther. 2018;11:5093-5101. doi:10.2147/OTT.S165511
OncoTargets and Therapy

\section{Publish your work in this journal}

OncoTargets and Therapy is an international, peer-reviewed, open access journal focusing on the pathological basis of all cancers, potential targets for therapy and treatment protocols employed to improve the management of cancer patients. The journal also focuses on the impact of management programs and new therapeutic agents and protocols on patient perspectives such as quality of life, adherence and satisfaction. The manuscript management system is completely online and includes a very quick and fair peer-review system, which is all easy to use. Visit http://www.dovepress.com/ testimonials.php to read real quotes from published authors. 